\title{
War Strategy Done by Gayo and Alas People Against Dutch Colonial (1901-1912)
}

\author{
Hairul Masri ${ }^{1}$, Suprayitno ${ }^{2}$ Ratna $^{2}$ \\ ${ }^{1}$ Master Student in Faculty of Cultural Sciences, North Sumatra University (USU),Medan, Indonesia \\ ${ }^{2}$ Lecturer in Faculty of Cultural Sciences, North Sumatra University (USU),Medan, Indonesia \\ nisanaceh@gmail.com
}

\begin{abstract}
The arrival of Dutch troops with marsose troops into the Gayo and Alas areas while attempting to crush local fighters led to wars in the area. By fomenting the spirit of war sabil, the fighters with local residents made war against the Dutch as a form of jihad against the unbelievers in order to maintain the area and belief of Islam is embraced. In the face of Dutch troops, the fighters in the Gayo and Alas region used several strategies, among which were the implantation of the Sabil War Ideology, warfare, and guerrilla warfare. Through the implementation of the strategy, the fighters are able to provide fierce resistance and can survive for a long time against the attack of Dutch troops. The Gayo and Alas people's resistance has begun to dwindle since some of the leaders of the fight have been killed and captured by Dutch troops. This led to a decline in resistance because it was no longer well organized as the combatants lost their command.
\end{abstract}

Keywords: war strategy; Gayo and Alas; Dutch colonial.

\section{INTRODUCTION}

The presence of a foreign nation into a new territory often creates resistance from rulers as well as local residents due to fears of loss of power and their freedom. Such a thing also took place in the archipelago, which is since the presence of the Dutch which led to resistance by the 
people to drive the foreign troops from the homeland. Resistance against the Dutch took place in various regions led by the struggling figures. In some areas, the war against the Netherlands produced unforgettable heroic stories such as those that took place in the war between the people of Aceh against the Dutch troops. The resistance that the Acehnese people made during the war against the Dutch became an unforgettable event for the foreign nation. The endless resistance of the people, coupled with the implementation of a very good strategy by the fighters, has earned the recognition of the Dutch themselves that the people of Aceh have actually waged a universal war. The privilege of the resistance in Aceh is that war is not only an attempt to expel the enemy, but is interpreted as a jihad for the sake of maintaining trust and succeeds in giving great resistance. The great resistance of the people in Aceh is also supported by the inhabitants from the hinterland, precisely from the Gayo and Alas regions. The area became one of the most powerful sources of power during the war on the Aceh coast. The magnitude of the role of the Gayo and Alas people which eventually became the reason for the Dutch to conduct "war expedition" to the region. The arrival of the Dutch who brought troops in large numbers coupled with the marsose did not make the population tremble. They refused to surrender and tried to defend their territory, resulting in a war between Gayo and Alas against the Dutch troops. The war between Gayo and Alas people against the Dutch troops was part of the Aceh war. War in the region began since 1901, when the Dutch troops successfully through the thick forest until finally reached the area Takengon (Gayo). Since then, militants in the Gayo and Alas region have continued to fight against the territory, homeland and Islamic beliefs embraced by Dutch troops.

\section{THE ENTRY OF DUTCH TO GAYO AND ALAS}

Before the Dutch entered Gayo and Alas region, the area was an inland area that had never been visited by foreign nations. The first voyage of Dutch troops into the Gayo region took place in 1901 under the leadership of Van Dalen who still held the rank of Major. Dutch troops successfully entered Takengon(Gayo) and explored the area around the Bargaining Sea to search for the presence of the Acehnese Sultan and other Aceh warriors, who fled to the area and made it 
their base of defense. Van Daalen in his search for the Gayo region carried 12 troop brigades which took place from September to November 1901 In 1902, Dutch troops made a "trip" four times to the Gayo region. The journey in entering the Gayo area is done from a different direction. The first troops under Captain JHL. Scheiders move from Kuala Simpang direction to Serbejadi. Meanwhile Captain Van Der Maaten's troops depart from Samalanga to Ketol and continue on to Gayo Laut and the Deret. In addition, Captain Scheepens along with his troops also traveled to the Gayo region. the troops depart from Meureudu to Pameu which is believed to be the hiding place of Tuanku Muhammad Daud (Sultan of Aceh). Another trip was made by Captain Colijn, who departed from Pase North Aceh to Samarkilang, then entered Isak, Linge, to Burni Intem In the area, Dutch troops had failed due to fierce resistance from local fighters. In the battle the Dutch lost an officer named G.J.H Van Stein who was killed by a fighter attack. The failure of forces in his expeditions provided valuable information to be aware of the presence of fighters in the region. After that, the journey to the hinterlands of Aceh was again carried out by the Dutch troops in 1904. Van Heutsz who served as Dutch Military Governor in Aceh ordered troops to perform "expedition" to the area of Gayo and Alas. The command to the commander of the troops was to visit the Freshwater, calling customary chiefs, discussing the formation of administrative government, and summoning the king of Linggo. In addition, the troops were also ordered to finish all the resistance that people do, visit the area of Alas, and then into the Land of Batak. On the trip, the troops led by Van Dalen who had the rank of lieutenant colonel with 10 marsose brigades, 12 best officers, and 450 forced laborers to lift supplies and weapons of war. On the way, Van Dalen also brought JCJ. Kempees who served as his adjutant, as well as PJ. Jansen is a mining engineer to investigate important materials in the region. So from February 8 to July 23, 1904, the Dutch troops along with marsose conquered the Gayo and Alas region. Van Dalen's Dutch troop trip to the Gayo and Alas region did not go easy because it must pass through a steep wilderness. Van Dalen in his report wrote how difficult the journey that must be taken by his troops to get to the destination. On the way, when they arrived at a township, the Dutch troops made the arrest and the village leader got a fine (paying some buffalo), for not reporting himself after being ordered. Meanwhile, on expeditions to the Gayo and Alas regions, 
the Netherlands also set out another troop, the "car troops" who traveled from different directions. The troops moved from Kuala Simpang, led by Captain Cruetsz Lechleitner, and assisted by Harbord, Vesling, Van Boldrik, Delgorge and Lasonder, along with second-class De Granada health officers. The number of troops that departed the power of about 150 bayonets. The route traveled by the troops is through the village of Jihih, Tampor, to Pining in Gayo Lues area, then will join with Van Dalen troops who came from Isak to Jagong. Judging from the Dutch troop routes traveling from two different directions, it indicates that they want to quickly eliminate the Gayo and Alas fighters. The departure of troops from different directions also implies that the Dutch wanted to break the concentration of the fighters and prevent them from getting help from the Aceh coast. In this way, the Dutch were convinced that they would be able to conquer Gayo and Alas areas easily so that their mission could be accomplished in accordance with the instructions given.

\section{SABIL WAR IDEOLOGY}

Sabil war Idea became one of the sources of people's struggle power throughout Aceh, including in the Gayo and Alas regions. The ideology is very influential in the struggle against the Dutch because it is able to bear the spirit of the people to plunge into the battle against enemies who are considered infidels. With the growth of the Sabil War Idea, the resistance against the Dutch became a holy war or war in the way of Allah, which must be implemented because it aims to protect the religion, the homeland and the Islamic community from the invaders. The people who grew up and deeply instilled Islamic values, understood the importance of fighting the disbelievers (the Dutch). There is not the slightest doubt in them to do jihad fi sabilillah when the country is harassed by foreign nations. They are willing to sacrifice their lives to defend their beliefs. In the spirit of the war of sabil, there is no more worry in them if later should die in battle, because it is part of jihad that will get a pleasant reply in En lo sucesivo one day. The spirit of sabil wars that grew within the Gayo and Alas peoples became a jihad that had been done before the Dutch entered their territory. At the time of the war on the coast, the people 
of Gayo and Alas helped the struggle of the people of Aceh to expel the Netherlands by sending its fighters to the coast of Aceh. In addition, in a report written by Snouck Hurgronje, shows that Gayo and Alas residents regularly contribute to sabil funds for the sake of the Aceh coastal struggle. The growing sense of unity between Gayo and Alas residents with the Acehnese people cannot be separated from the understanding of the meaning of war sabil, so that they jointly struggle to protect the region of Aceh from foreign attacks. The emergence of the spirit of war sabil throughout Aceh including in the area of Gayo and Alas driven by the scholars and leaders of war. The clerics in Aceh are not only limited to their functions and role as teachers in dayahs, but he also appears in the social field as a leader or role model of the ummah. When his country was in danger, the clerics also appeared to lead the battle as had Tengku Imum Luengbata, Teungku Chik Di Tiro, Teungku Chik Tanoh Abee and others. Under the guidance of the ulama, the war against the Dutch had a deeper meaning, for it was not merely to sustain life in the defense of the land, but also as a spiritually meaningful act. The value of warfare becomes more sacred, and sacred, because dying in a state of war does not mean the end of life, but the beginning of a pure and eternal life and promising endless happiness In cultivating the spirit of war of sabil to the inhabitants, the scholars cited many verses in the Qur'an. In addition, the scholars also use the saga as a medium to raise the spirit of the people. The scholars who are adept at writing stories include Tengku Chik Kutakarang, Tengku Chik Pante Kulu, and Tengku Chik Di Tiro. The scholars have a big part in writing saga as a medium of religious communication with the community, so as to be able to move their hearts to fight against the Dutch Meanwhile in the Gayo and Alas region, the war saga is also spread as a propaganda medium. Evidence of the influence of war stories in the region can be seen from the Van Daalen report on the expedition, he found a number of books that have been left by residents in the area of Karang Ampar (Gayo). According to Dutch records, Van Daalen found forty-six Arabic books, among them are the selected books written by Syeck Saman Di Tiro, Sabil Hikayat War and the old books. Meanwhile, when Captain Schepens entered the Semelet (Gayo) area, he also found several religious books that the people had left behind when Dutch troops arrived. The Idea of Sabil War became an important part in the story of the struggle of the people in Aceh, 
including in the Gayo and Alas regions so that the inhabitants from men, women, and children, played a role in fighting Dutch troops. The ideology is able to eliminate the fear in them despite having to deal with a strong enemy. It was not uncommonly found in a battle, a woman using a sword in her hand attacked a marsose troop holding a gun while shouting "Allahu Akbar". The growth of courage cannot be separated from the embedded spirit of sabil war in them so there is no doubt in the slightest to fight the enemy who was in front of him.

\section{CASTLE WAR STRATEGY}

One of the strategies used by residents in Gayo and Alas in the face of Dutch troops is to use the castle as a base of defense. Establish a castle is a form of local wisdom that the population used as a refuge from the attacks of wild animals that enter their village. By the time the Dutch troops arrived, the fortresses were used as a refuge for them as well as a place to attack the enemy In the face of Dutch troops, the inhabitants erected ten fortresses that were made gradually in the strategic kampongs. The fort was built from the ground using stones, and around it was made a spiked thorn wooden fence and covered with bamboo spiny plants. The fort was built in a large size that has a length of about $54 \mathrm{~m}$ and $42 \mathrm{~m}$ width. Inside the fort, the people placed traditional weapons such as swords, rudus, mermu, spear, rencong, and "spray water sprayer". In addition, they also use weapons known as "ali-ali weapons" that serve to throw stones and pieces of spiky wood to the enemy. Before the war began, all the inhabitants of the village men, women, and children were ordered to enter the fortress. They use white clothing as a symbol that the war encountered is holy war and will soon get a pleasant reply in the afterlife. In their minds, there is no desire to surrender and as much as possible to fight against an enemy that is considered to be a kafir. The kings in every village usually appear to be leaders of war for their inhabitants. They are also in charge of arranging the placement of the position of the fighters and leading the prayers before the start of the war. The kings with the inhabitants instilled confidence in themselves so there was no hesitation in the face of the Dutch troops ready to attack them. Meanwhile, before the Dutch attack usually first send a letter to the population through the accomplice named Aman 
Syafii, a local resident who became the Dutch accomplices in Gayo Lues and Berakan while in the area Alas. The letter sent contains orders to the villagers to immediately surrender and report to the Dutch, but it is always ignored because according to their understanding to submit to the unbelievers is a sinful act. Therefore, Van Dalen, who had lost his patience, ordered his troops to immediately attack the people and destroy the fortresses used as protection. On March 14, 1904, the Dutch troops with marsose began pounding the first fort built the inhabitants of Benteng Pasir. In the war at the fortress, the fighters tried to give resistance to the Dutch troops. The ready-made weapons are used to keep the enemy from entering the fort. The battle inside the castle witnesses the courage of the people in battle despite its shortcomings in various lines and only capitalizes the ancient warfare tools. From the Dutch report mentioned, the number of casualties in the battle is 41 people died, 27 of them died in the fort including 2 women wearing men's clothing and fighting, and 14 people were killed outside the fort. Meanwhile, from the Dutch side, the number of injured is 6 people.

After conquering the Sand Castle, the Dutch troops then moved towards the next village that had erected Fort Gemuyang. In the battle, when the marsose troops tried to approach the fort, the fighters responded by spraying fire, and throwing stones, and pieces of spiky wood. Nevertheless, the battle in the fortress could be resolved by Dutch troops in quick time. In his report, Kempees wrote the death toll in the battle was 308 people, consisting of 168 men, 92 women and 48 children. After that, the Dutch troops moved towards Durin Fort. Dutch troops attacked Durin Fort using 8 brigades, 3 brigades led by Lieutenant Schepeens, assisted by Lieutenant Aukses, 2 brigades led by Lieutenant Ebbink, 3 brigades under Lieutenant Winter as reserve troops, including health officer-led officer Neeb, 2 brigades led by Christoffel helped oversee the field. Meanwhile, troops led by Van Dalen served as reserve troops. After a fairly fierce battle, this fortress can be controlled by Dutch troops. The next fortress that the Dutch troops targeted was the Rhinoceros. The pattern of fighting carried out by the people in the region is still the same as in the previous fortresses. Residents in the area also still rely on ancient combat equipment as their weapons, so the Dutch have no trouble conquering them. After successfully knocking down the fort, Dutch troops then took weapons belonging to the fighters. 
In addition, groceries, valuables belonging to the people, as well as household appliances and jewelry were also taken. The fortress in Rikit Gaib was the fifth target of the attacks by the Dutch forces with marsose. In the village of Rikit Gaib, there are two fortress that borders one another that is Cane Uken Fort and Benteng Tungul (tungel), both enter into environment of Rikit Gaib. Construction of the fort became one of the strongest than the previous defense, so it is believed will be difficult for the Dutch troops. Although built more strongly, but the experience of the Dutch troops war is superior so that the people's resistance in the fortress can be completed. The Dutch troops journey to Castle. Unlike the others, the fort was built wider, stronger, and larger. Above the castle there are several places made especially for snipers and a place to stalk the enemy. While on the Dutch side, in the battle at the castle, they are helped by "troop cars" that have been up since traveling from Kuala Simpang. The presence of new troops became a significant addition to the Dutch troops, especially to increase the morale of his troops who had long engaged in fighting in the interior of Aceh. The presence of "car troops" proved capable of making Dutch troops to complete the battle at Fortress Penosan The people's last defenses in Gayo Lues are Benteng Tampeng, which is expected to survive the rigors of Dutch troops. Seeing in other areas that successfully trooped down Dutch troops, the people tried hard to make the fort became stronger than ever before. The fighters from others also helped the struggle of the people in the village. In the Dutch report mentioned, the Gayo fighters are led by Pang Aman Jerango, Aman Linting, Aman Jata, Rahel Bambel Abdussamad and a srikandi named Dimus. Kejurun Bambel mentioned deliberately came bringing the power of 30 people complete with weapons to help the people's efforts to defend his fort. After successfully fighting the people's resistance in Gayo Lues, Van Dalen with his troops began to move towards the Alas region, an area directly adjacent to the Gayo Lues region. In the area, the fighters along with the people established three fortresses that were used as defense, namely Fort Kute Reh, Fortress Likat, and Benteng Kute Lengat Baru. The pattern used by the people of Alas in building the fort is still the same as that of Gayo Lues people. This caused the Dutch troops not too difficult to conquer because they have experienced when knocking down forts of people's defenses in the area Gayo Lues The first attack of Dutch troops with marsose against the Kute Reh Fort was launched on July 4, 1904. The 
battle at Fort Kute Reh became one of the sad events that occurred during Van Dalen's expedition to Gayo and Alas. The tragedy at Fort Kute Reh was in the spotlight as a result of the nefarious treatment of Dutch troops against the population. The action in question was when the Dutch troops killed almost all the inhabitants inside the castle, causing criticism from various parties. Nevertheless, the Dutch troops seemed unaffected by the blasphemy that came and continued its aggression. In a report written by Kempees, the number of people who died on the incident was 561 people, 313 men, 189 women and 59 children. The battle at Fort Kute Reh afterwards remained in the spotlight due to Dutch abominations, the battle also depicts the story of local courage in battle. It is a clear fact that the mass resistance that took place in Kute Reh involved a large number and almost all of its people died from the ferocity of the war. In his report, Kempees wrote before the Dutch troops carried out the attack, a loud voice inside the fort shouted "Allahu Akbar" and all the inhabitants wore good clothes. As a result of this, the Dutch troops made crackdowns to paralyze those inside the fortress. After completing the attack on Fort Kute Reh, the Dutch continued the battle on the next two buffs of Benteng Likat and Benteng Kute Lengat Baru. Like the others, the two fortresses were also destroyed by the greatness of the Dutch troop attacks. After destroying the fortress in the Alas area, the entire forts of people's defenses in the Gayo and Alas region have been destroyed by Dutch troops. The Dutch troops' mission to defeat the resistance in Gayo and Alas is said to be over, then the Dutch troops continue their journey towards Batak Land according to the given orders. Although the Dutch troops were considered successful completing their expeditions to the Gayo and Alas regions, it left a grim note to the locals. During five months of adventure in the interior of Gayo and Alas, Van Daalen along with his troops had killed the population in a cruel way. Thousands of men, women, and children were raided with guns, rice barns and enclosed villages burned according to the Van Heutsz method. In its report, Kempees wrote that the number of Gayo and Alas casualties reached 2,922, consisting of 1,773 men and 1,149 women. The Dutch themselves lost 26 soldiers who were killed, while 72 others were injured and taken to Medan for treatment. 
Table 1

Number of Victims of Attack Done by Dutch Troops to Gayo and Alas

\begin{tabular}{|c|c|c|c|}
\hline Date & Location & Male victim & $\begin{array}{c}\text { Victims of Women } \\
\text { and Children }\end{array}$ \\
\hline $14 / 3 / 1904$ & Pasir & 149 people & 15 people \\
$18 / 3 / 1904$ & Gemuyang & 168 people & 140 people \\
$22 / 3 / 1904$ & Durin & 164 people & 15 people \\
$4 / 4 / 1904$ & Badak & 193 people & 45 people \\
$21 / 4 / 1904$ & Rikit gaib & 143 people & 41 people \\
$11 / 5 / 1904$ & Penosan & 200 people & 94 people \\
$18 / 5 / 1904$ & Tampeng & 176 people & 51 people \\
$14 / 6 / 1904$ & Kute reh & 561 people & 248 people \\
$20 / 6 / 1904$ & Likat & 432 people & 212 people \\
$24 / 6 / 1904$ & Lute lengat baru & 654 people & 310 people \\
\hline
\end{tabular}

Source: JCJ. Kempees, De Tocht van Overste Van Dalen door de Gajo, Alas, en Bataklanden. 1905.

Although the Gayo and Alas people suffered defeat in the war, the fierce opposition shown against the Dutch troops continued to gain appreciation. Paul Van't Veer in his book wrote that the opposition of the Gayo and Alas people is special, he thinks these people deliberately confine themselves in fortified fortresses. They welcomed marsose with sacred readings and white clothing worn, as if to symbolize that they were ready to die. The unbelieving fanatical resistance is reinforced by stories that will befall women and children when falling into the hands of infidels, so that it can encourage the emergence of great resistance.

\section{GUERRILLA WAR}

After all the people's defenses in Gayo and Alas were destroyed by Dutch troops, the surviving fighters began to flee to other areas such as Gayo Laut, Gayo Deret and Alas, joining 
other fighters to continue the guerrilla war. Although the Dutch troops thought it had mastered several important areas during its expedition, there were still many warlords, kings, clerics, and people who would not give up. They retreated to the mountains to prepare for the next attack on the post or convoy of Dutch troops. The warrior leaders came back to set up new tactics in an attempt to expel Dutch troops from the Gayo and Alas regions. In the Takengon area (Gayo), attacks against the Dutch were led by Prang Amien commander, commander of Prang Bramat, commander of Prang Pren, Petoe Poetih, Petoe Leman, Penghoeloe Lot, Penghoeloe Pertik, Pang Doellah, Pang Lateh, Rodjo Poetih, Rodjo Kahar, Gombang, Aman Gantia and Lahidin. In addition, fighters from the coast of Aceh also support the struggle of the people such as Teuku Di Paya Bakong and Teuku In West. To streamline the command wire, they are assisted by Guru Sekindol and Pang Jongok. In addition, Teuku Ali Mukim Baet also makes Aceh Tengah (Gayo) the base of his defense. Mountainous natural conditions are used to formulate strategies in cooperation with nature. One of the ways that combatants often do is to drain large boulders from the steep hillsides toward the convoy of Dutch troops passing under them. Caves in the body of the hill serve as a hideaway for women and children. Some of the caves are also used as a post to spy on Dutch soldiers. Meanwhile, from the Dutch side, to end all the "revolts" that re-emerged, the Dutch Military Governor in Aceh issued an order to the troops to continue the sweep to the Gayo region. The sweeping was mainly done to pursue Acehnese warriors, such as Teuku Ali Baet who fled to Laut Tawar area and was suspected of reviving the people's resistance. One of the guerrilla warfare that took place between Gayo fighters and Dutch troops occurred in 1905 in a battle in the Burni Sange area. This place is so named because of the growing Sange (rattan) that is strategic enough to conduct guerrilla warfare. In addition, at night the place is very difficult to pass because it is prepared as a battleground. In the war, the fighters made a rope mounted along the road as a signal to initiate the attack. They had prepared well for fighting in the region with the Dutch army. Despite the fierce fighting, there was no definitive data on the number of casualties in the incident. Other battle events take place in an area called Bur Kul (hill area in Gayo). In the war, the Dutch deployed 2 brigade troops to pursue leader of the fighter named Pang Ramung. At the time of the battle, the fighters chose to retreat step by step in the 
hope that the Dutch troops would be exhausted, while waiting for the sun to set in and do a melee war. The Dutch troops moved forward unexpectedly that they had fallen into the trap of fighters, resulting in close combat that caused casualties on both sides. Meanwhile, during the war in the area of Gayo Laut, guerrillas under the leadership of Pang Bedul Mampak also tried several times to attack the Dutch troops. One of the most successful attacks was when it attacked and destroyed the Dutch headquarters in the Samarkaling area, which is about $40 \mathrm{~km}$ from Takengon. In the event, Pang Bedul Appear with his troops managed to kill almost all soldiers marsose, except 2 people who can escape. Information about guerrilla warfare that took place in the Gayo region was also written in the Dutch report. In colonial verslag (1906) it was written when a warlord named Tengku Muda Pendeng attacked the Dutch at Bivak Ampa Kolak (Takengon). The attack resulted in a sergeant and seven other soldiers suffering injuries. In addition, another attack was also carried out by one of the leaders of the struggle at Gayo named Reje Poteh, who attacked the Dutch headquarters in Pegasing (Takengon). The incident caused the 3 Dutch soldiers to be injured. After the incident, the Dutch continued to pursue Reje Poteh until he was finally arrested in 1907. The opposition of Gayo and Alas fighters is a form of self-defense in accordance with the principles of guerrilla warfare. Guerrilla tactics are to bind as many enemies as possible, exhausting, squeezing blood and sweat, and shaking his nerves. Guerrilla strategy can be applied by Gayo and Alas fighters, because of its very supportive natural conditions with the existence of valleys, hills, and mountains. The fighters use tactics and guerrilla warfare strategies according to their distinctive patterns and patterns. They comply with their own initiative if there is a chance to attack abruptly and then immediately retreat to the mountains if the situation is more difficult. The guerrilla resistance that the fighters continue to make makes the Dutch seem nervous. Snouck Hurgronje in his letter (1906) writes that it is impossible to see villages hostile to the Dutch will surrender as long as no action has taken place. Snouck adds that as long as T. Ben Blang Pidie and his followers have not been caught, the population will also be against it so it will be hard to see peace in the Linggo and part of the Freshwater. To overcome the guerrilla resistance of the fighters, Dutch Military Officers in Koetaradja issued instructions to increase the number of patrol troops to Gayo. The addition of troops to the heated region is expected to stop the 
resistance and strengthen the Dutch military posts around the area of the Bargaining Sea (Gayo). In addition to adding strength in the central part of Aceh, the Gayo region, the Netherlands also dispatched about 300 to 400 other troops to Blang (Gayo Lues area bordering Alas) to overcome resistance from "rebels". The presence of orders to increase the number of troops to the area of Gayo and Alas indicates that the Netherlands is experiencing panic due to attacks that continue to do the fighters. With the arrival of additional troops, the Netherlands hopes to immediately control the situation that had heated up. In addition, Dutch troops also intensified to conduct military operations to pursue fighters to the forests in order to end the resistance in the region.

\section{THE RETREAT OF GAYO AND ALAS PEOPLE'S STRUGGLE}

Along with the addition of troop and incessant Dutch operations throughout Aceh, it began to affect the decreasing intensity of resistance given by the fighters, especially after 1912. The resistance that previously had increased, began to decline after the leaders struggle began to fall and some arrested by Dutch troops. Reduced leaders of the struggle in the Gayo and Alas region occurred almost simultaneously with the coastal areas of Aceh. After influential warlords on the Aceh coast such as Teuku Di Paya Bakong and Teuku In the West were paralyzed by Dutch troops, the people began to lose the command of the struggle. Losing the figure of a war leader as well as a charismatic cleric like them is a loss felt by the fighters. Meanwhile in the Gayo area, the decline of the struggle began since Teuku Ali Mukim Bait and two of Teuku Umar's sons who came from the coast surrendered to the Dutch. The leaders of the coastal struggle were instrumental in reviving the resistance in the interior. In addition, they help and train the new fighters to be prepared into the battlefield, so after they surrender is very detrimental to other fighters. After that, the Gayo fighters lost their leader after Pang Muda, who headed the Muslim ranks in Rerobo (Gayo) surrendered to the Dutch in February 1911. In addition to Pang Muda, two religious leaders who later surrendered were Leube Grondong on 28 June 1912. Young Kuto Sre on August 13, 1912. 


\section{CONCLUSION}

In the face of Dutch troop attacks, it appears that the Gayo and Alas peoples have used some of the strategies to counter the resistance even though it was ultimately defeated by the Dutch. The defeat of the Gayo and Alas peoples in the war was caused by several factors, such as the unequal strength of both sides. The Gayo and Alas peoples in the war only used ancient weapons as combat gear, while Dutch troops came with equipment and sophisticated weapons. Another factor causing the defeat of Gayo and Alas people in the war was due to lack of modern war science and tactics. The fighters use tactics based on knowledge of the circumstances surrounding them. In addition, war tactics are run only based on experience gained while in the field so sometimes less effective. This is different than the Dutch troops who have experienced in terms of war so that the resistance of Gayo and Alas people can be crushed. Although in the war the Gayo and Alas peoples finally had to bow to the Dutch troops, but the resistance shown in protecting the Islamic beliefs and territories embraced could be a force that could make it difficult for the Dutch. Thus for the people of Gayo and Alas, the resistance against the Dutch is not only worth the war alone, but it is jihad that is done because it is based on the belief to defend the territory, the homeland, as well as the sanctity of Islam.

\section{REFERENCES}

Algemeene Secretarie Grote Bundel TZg Agenda tahun 1891-1942 No. 6567

Algemeene Secretarie Grote Bundel TZg Agenda tahun 1891-1942 No. 8342

Ahmad, Zakaria, dkk. 1982. Sejarah Perlawanan Terhadap Imprealisme dan Kolonialisme di

Daerah Istimewa Aceh, Jakarta: Proyek Inventarisasi dan Dokumentasi Sejarah Nasional.

Alfian, Ibrahim. 1987. Perang di Jalan Allah: Perang Aceh 1873-1912. Jakarta: Pustaka Sinar Harapan.

Daalen, Van. 1905. Verslag van den tocht naar de Gajo en Alaslanden. Batavia Gayo, M.H. 1983. Perang Gayo Alas Melawan Kolonial Belanda, Jakarta: Pustaka Sinar Harapan. 
Gobee dan Adriaanse. 1990. Nasehat-Nasehat C. Snouck Hurgronje Semasa Kepegawaiannya di Hindia Belanda 1889-1936 Jilid III. Jakarta: INIS.

Hurgronje, Snouck. 1990. Het Gajoland en Zijne Bewoners, Terjemahan Budiman. Jakarta: INIS. Jongejans. 1939. Land en Volk van Atjeh Vroeger en Nu, Baarn: Hollandia Drukkerij.

Kaliwarang, Hary. 2008. Aceh dari Iskandar Muda ke Helsinki, Banda Aceh: Bandar Publishing.

Kempees, JCJ. 1905. De Toch van Overste Van Daalen door de Gajo, Alas en Bataklanden.

Kolonial Verslag, 1906.

Kolonial Verslag, 1908.

Latief, AR. Pelangi Kehidupan Gayo dan Alas, Bandung: Kurnia Bupa. (Tanpa Tahun Terbit).

Maaten, K Van Der. 1978. Watak Berperang Bangsa Indonesia di Berbagai Daerah: Suatu Perbandingan, Banda Aceh: Pusat Dokumentasi dan Informasi Aceh.

Madjid, M. Dien. 2014. Catatan Pinggir Sejarah Aceh: Perdagangan, Diplomasi, dan

Perjuangan Rakyat, Jakarta: Yayasan Pustaka Obor Indonesia.

Munawiyah. 2007. Birokrasi Kolonial di Aceh, Banda Aceh: IAIN Ar-raniry.

Nasution, A.H. 1953. Pokok-pokok Gerilya, Yogyakarta: Pustaka Narasi.

Said, Mohammad. 2007. Aceh Sepanjang Abad Jilid 2, Medan: Harian Waspada.

Sufi, Rusdi, dkk. 2008. Aceh Tanah Rencong, Banda Aceh: Pusat Dokumentasi dan Informasi Aceh. 2008. Sejarah dan Adat Istiadat Masyarakat Alas di Aceh Tenggara, Banda Aceh: Badan Arsip dan Perpustakaan Provinsi Nanggro Aceh Darussalam.

Veer, Paul Van't. 1985. Perang Aceh: Kisah Kegagalan Snouck Hurgronje, Jakarta: Grafiti Press.

Zentgraaff, H.C. 1983. Atjeh, Jakarta: Departemen Pendidikan dan Kebudayaan. 